\title{
Evaluation of functional arterial spin labeling data using a perfusion template
}

\author{
Jan Petr ${ }^{2,3^{*}}$, Elise Bannier ${ }^{4,5}$, Hélène Raoult ${ }^{1,2}$, Jean-Christophe Ferré ${ }^{1,2}$, Jean-Yves Gauvrit ${ }^{1,2}$, Christian Barillot ${ }^{2,3}$ \\ From Twentieth Annual Computational Neuroscience Meeting: CNS*2011 \\ Stockholm, Sweden. 23-28 July 2011
}

ASL allows non-invasive imaging and quantification of brain perfusion by magnetically labeling blood in the brain-feeding arteries. In this study, a template created from perfusion images of 25 resting healthy subjects was used to automatically detect hyper perfusion patterns of 8 other subjects. DARTEL registration was used to improve the precision of the template and partial volume correction to prevent interpolation artifacts.

MR imaging was performed on a 3T MR scanner with a 32-channel head coil and consisted in a $1 \times 1 \times 1 \mathrm{~mm}^{3}$ 3D T1 and a PICORE Q2TIPS ASL with $3 \times 3 \times 7 \mathrm{~mm}^{3}$ pixel size, $\mathrm{TR} / \mathrm{TE}=3000 / 25 \mathrm{~ms}, \mathrm{TI}=1700 \mathrm{~ms}$ and Q2TIPS saturation [3] at $700 \mathrm{~ms}$. ASL images were acquired in 25 healthy subjects (mean age 31.6). Additionally, 8 healthy right-handed subjects underwent fASL study following a bloc-design experiment with seven interleaved 30s-phases of rest and motor task of the dominant hand. The following processing was applied: a) Perfusion was quantified [2]; b) ASL images were co-registered with their T1 images; c) T1 images were segmented to GM/WM regions; d) Partial volume effects in ASL images were corrected for using high-resolution segmentation [4]; e) T1 images were aligned to the ICBM-152 template [5]; f) T1 images were aligned using DARTEL registration [1]; g) ASL images were spatially normalized using the transformations from $\mathrm{e}, \mathrm{f}) ; \mathrm{h})$ The perfusion template was created as the mean and variance of the spatially normalized ASL images of the 25 resting subjects. For each of the 8 fASL subjects, the activated image was created by averaging the images acquired during activity phases. Hyperperfused areas were identified by comparison with the template $(\mathrm{p}<0.001)$. To examine false positive hyperperfusion detection, hyper-perfusion areas were assessed on each of the 25 patients using a template created from the 24 remaining patients.

\footnotetext{
* Correspondence: jan.petr@irisa.fr

${ }^{2}$ INRIA, VisAGeS Project-Team, F-35042 Rennes, France

Full list of author information is available at the end of the article
}

Standard fASL processing was performed by using SPM8 using 6-mm FWHM Gaussian spatial smoothing and GLM model with statistical significance $\mathrm{p}<0.001$. Regions corresponding to primary motor and supplementary motor cortex were manually selected and were used to evaluate the results of template comparison. The ratio of hyperperfusion false positive detection was below $1 \%$ for all subjects. The hyperperfused areas obtained with template comparison represented $86,0 \pm 10,1 \%$ for the primary motor cortex region and $79,9 \pm 9,3 \%$ for the supplementary motor cortex of the ground-truth obtained by standard Bayesian analysis. Using the Bayesian model, the supplementary motor cortex was not detected at all in one patient and this dataset was not taken into account. Figure 1.

\section{Conclusions}

This study shows that a perfusion template can be used to assess task-related activation zones in functional ASL

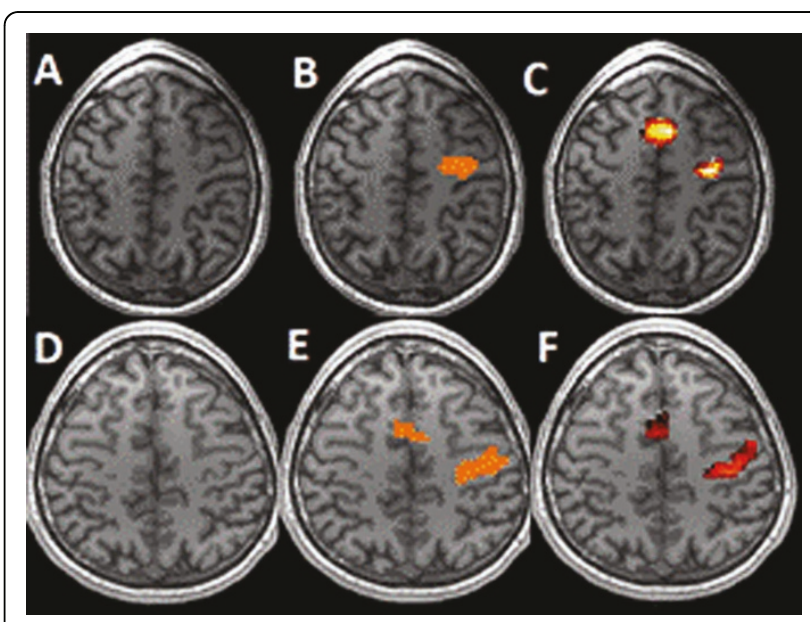

Figure $\mathbf{1}$ Task-related activation zones of two patients. A, D. T1 image. B, E. SPM detection. C, F. Comparison with template.

\section{() Biomed Central}

(c) 2011 Petr et al; licensee BioMed Central Ltd. This is an open access article distributed under the terms of the Creative Commons Attribution License (http://creativecommons.org/licenses/by/2.0), which permits unrestricted use, distribution, and reproduction in any medium, provided the original work is properly cited. 
data while using only activated phase. Two assumptions can be made to explain why standard functional analysis yields slightly larger activation regions. First, the use of FWHM 6mm Gaussian kernel possibly enlarges the detected zones. Second, the data analyzed using SPM contains both resting and activated phases whereas only the activated phase was compared to the template. Future work will focus on detection of hyperperfusion in different neurodegenerative diseases taking into account registration issues of pathological T1 images.

\section{Author details}

'Neuroradiology Dept., University Hospital of Rennes, F-35043 Rennes, France. ${ }^{2}$ INRIA, VisAGeS Project-Team, F-35042 Rennes, France. ${ }^{3}$ INSERM, U746, F-35042 Rennes, France. ${ }^{4}$ University of Rennes I, CNRS, UMR 6074 IRISA, F-35042 Rennes, France. ${ }^{5}$ Neurinfo Platform, University Hospital of Rennes, F-35043 Rennes, France.

Published: 18 July 2011

\section{References}

1. Ashburner J: A fast diffeomorphic image registration algorithm. Neurolmage 2007, 38:95-113.

2. Buxton RB, Frank LR, Wong LC, Siewert B, Warach S, Edelman RR: A general kinetic model for quantitative perfusion imaging with arterial spin labeling. Magn Reson Med 1998, 40:383-396.

3. Luh WM, Wong EC, Bandettini PA, Hyde JS: QUIPSS II with thin-slice TI1 periodic saturation: a method for improving accuracy of quantitative perfusion imaging using pulsed ASL. Magn Reson Med 41:1246-1254.

4. Petr J, Ferre JC, Gauvrit JY, Barillot C: Denoising ASL MRI using tissue partial volume. SPIE 2010.

5. Mazziotta JC, Toga AW, Evans A, Fox P, Lancaster J: A Probablistic Atlas of the Human Brain: Theory and Rationale for Its Development. Neurolmage 1995, 2:89-101.

doi:10.1186/1471-2202-12-S1-P9

Cite this article as: Petr et al:: Evaluation of functional arterial spin

labeling data using a perfusion template. BMC Neuroscience 201112 (Suppl 1):P9.

\section{Submit your next manuscript to BioMed Central} and take full advantage of:

- Convenient online submission

- Thorough peer review

- No space constraints or color figure charges

- Immediate publication on acceptance

- Inclusion in PubMed, CAS, Scopus and Google Scholar

- Research which is freely available for redistribution

Submit your manuscript at www.biomedcentral.com/submit
C Biomed Central 